\title{
Undergraduate training in ENT Head and Neck Surgery In Nepal : Is there any uniformity?
}

R Guragain

R Bhatta

Ganesh Man Singh Memorial Academy of ENT and Head and Neck Studies,

TU Teaching Hospital,

Kathmandu, Nepal

\section{Correspondence to}

Dr. Rishi Bhatta

Ganesh Man Singh Memorial

Academy of ENT and Head and Neck

Studies, TU Teaching Hospital,

Kathmandu, Nepal.

Email: rishi_31@yahoo.com

AIMS AND OBJECTIVES

To compare the ENT-Head and Neck Surgery training program of MBBS students of different universities and institutions of Nepal and India.

\section{MATERIALS AND METHODS:}

A descriptive cross-sectional study was conducted in the form of rolling audit in Ganesh Man Singh memorial Academy of ENT Head and Neck Studies, Kathmandu, Nepal. The undergraduate (MBBS) curriculum of Institute of Medicine (I.O.M), Tribhuwan University (T.U.)., Kathmandu University (K.U.)., BP Koirala Institute of Health Sciences(BPKIHS), All India Institute of Medical Science(AIIMS) and other medical colleges under Medical Council of India(MCI) were studied and compared.

\section{RESULTS:}

Practical exposure was more in TU training where as more time (almost $50 \%$ ) were devoted in theory lectures in KU.curruculum. Logbook maintenance and internal examinations were lacking in most universities. ENT training was optional during internship in KU, BPKIHS and AIIMS.

\section{CONCLUSIONS AND RECOMMENDATIONS:}

As there was no uniformity in the undergraduate training in ENT Head and Neck Surgery in Nepal, the concerned institutions like Nepal Medical Council and Society of Otolaryngologists of Nepal should take an initiative to make the training uniform which will help to control the quality of ENT Head and Neck Surgery practices in this country.

Keywords: MBBS curriculum, Tribhuwan University (T.U.), Kathmandu University (K.U.), BP Koirala Institute of Health Science (BPKIHS), All India Institute of Medical Science (AIIMS), NMC (Nepal Medical Council)

\section{INTRODUCTION:}

Quality control in medical education in Nepal is one of the hot topic nowadays, mainly because of mushrooming up of medical colleges in the private sector. This matter is also relevant because of Nepalese students being graduating abroad and practicing medicine in Nepal afterwards. During the last decade there has been tremendous increase in the opening up of new medical colleges and also the Nepalese students going abroad for training in medicine.There are at present four universities in Nepal. Tribhuvan university and Nepal Sanskrit Universities are the older one while Kathmandu University and the Purbanchal University are the newer ones. However, only two of them Tribhuvan and Kathmandu universities affiliate for medical training to six medical colleges each. Besides these, there are three autonous institution in the country which provide medical education - BPKIHS in eastern Nepal and NAMS Bir Hospital (only postgraduate training) and Patan University of Health Sciences in the Kathmandu very. Every year increasig number of medical graduates are registered in the Nepal Medical Council, who were trained other than above mentioned universities or institutes. This number is even expected to increase in years to come. Looking at the diversity of training institutes, the quality of training in ENT Head and Neck Surgery like in other specialities is a matter of concern. This article compares the training among different institutes of Nepal and also to that of India wihich is supposed to be gold standard in this region.

\section{MATERIALS AND METHODS}

A descriptive cross-sectional study was conducted in the form of rolling audit in Ganesh Man Singh Memorial Academy of ENT Head and Neck Studies. MBBS training in ENT Head and Neck Surgery was studied in detail regarding theory and the practical classes, duration, subdivision of the group, exposure to OPD, OT, bedside teaching, audiology, speech therapy and lecture topics and examination system. New syllabus recommended by ENT/HNS department of IOM was also studied. ${ }^{1}$ Similarly, the syllabus of Kathmandu university $(2006)^{2}$ and BPKIHS, Dharan ,Nepal (1996) ${ }^{3}$ in MBBS ENT training were studied. Current schedules of undergraduate training at AIIMS $(2005)^{4}$ and other medical colleges of India under $\mathrm{MCl}$ (1997) were obtained from their web sites and was compared to the training in Nepal.

The following aspects were compared :

1) Aims and Objectives of undergraduate program in ENT and Head and Neck Surgery

2) Duration of Course

3) Knowledge

a. Theory classes(lectures)-topics covered

b. Seminars by students themselves

c. Tutorials and problem based learning

4) Skills

a. Ward Clinical Teaching( history taking/ clinical examination)

b. OT exposure(instruments/procedures)

c. Emergency management

5) Teachers: Students Ratio/ Bed :Students ratio

6) Evaluation

a. Logbook

b. Examination System

\section{RESULTS:}

The first objective of all institutions studied was to learn basic principles and practice of ENT followed by curative and management of patients and then Preventive aspects. AlIMS also focused on performing minor surgical procedures. New syllabus of IOM aims an appropriate and timely referral to experts. Durations allocated for theory and practical classes are given in table1 which shows less theory classes in T.U., and BPKIHS. Regarding time for clinical teaching it is highest in T.U. with 
Table 1: Time allocated in curriculum

\begin{tabular}{|l|l|l|l|}
\hline \multirow{2}{*}{ Institution } & \multicolumn{3}{|l|}{ Duration(hours) } \\
\cline { 2 - 4 } & Theory & Practical & Total \\
\hline T.U. & 45 & 162 (6weeks) & 207 \\
\hline K.U. & 80 & 120 (4weeks) & 200 \\
\hline BPKIHS & 56 & 84 (4weeks) & 140 \\
\hline $\begin{array}{l}\text { Indian Medical Colleges (under } \\
\text { MCI) }\end{array}$ & 70 & 144 (8weeks) & 214 \\
\hline
\end{tabular}

least in BPKIHS.Current syllabus of T.U. lacks theory lectures on Head and Neck lesions grossly, but this will be fulfilled in upcoming syllabus. Besides that, principles of Functional Endoscopic Sinus Surgery (FESS) will be included. Head and Neck malignancies are still not given importance in curriculum of K.U. and BPKIHS. AlIMS has focused on principles of common surgeries like myringoplasty, septoplasty, tympanoplasty in its curriculum. Seminar by MBBS has only been mentioned in BPKIHS curriculum and not even in curriculum of Indian medical colleges. This part will be covered in upcoming syllabus of T.U. Problem based learning $(\mathrm{PBL})$ though is being implemented in basic science of K.U. Medical School (KUMS); it has not been started in ENT/HNS. Clinical teaching focuses on history taking and methods of examination. Commonly used ENT instruments and procedures are taught along with $\mathrm{X}$ rays, models and specimens. This part is basically similar in different universities but in upcoming syllabus of T.U. operative procedures, endoscopy and ENT emergencies wii also covered. As per Nepal Medical Council (NMC) guideline ${ }^{5}$ there should be 7 beds per student of a batch and 25/700 beds should be for ENT. This is fulfilled by IOM and BPKIHS only. Similarly 6 teachers for 100 students per batch should be there which is fulfilled by IOM, BPKIHS, and some medical colleges of K.U.Evaluation of students has been mentioned to be done by log book in curriculum of T.U. and $\mathrm{MCI}$. Interval Examinations is being taken by K.U. and AlIMS but was left to individual medical colleges of India by $\mathrm{MCl}$. As per table 2

Table 2: Examination Marking System

\begin{tabular}{|c|c|c|c|c|c|c|}
\hline \multirow[t]{2}{*}{ INSTITUTE } & \multicolumn{2}{|c|}{ Internal assessment } & \multicolumn{2}{|c|}{ Final Examination } & \multirow[t]{2}{*}{ Total } & \multirow{2}{*}{$\begin{array}{l}\text { Passing } \\
\text { Requirement }\end{array}$} \\
\hline & Theory & Practical & Theory & Practical & & \\
\hline T.U. & 10 & 0 & 40 & $40+\operatorname{VIVA}(10)$ & 100 & $\begin{array}{l}50 \% \text { Theory \& Pract } \\
\text { each }\end{array}$ \\
\hline K.U. & 15 & 10 & $70+$ VIVA(15) & 40 & 150 & $\begin{array}{l}50 \% \text { Theory \& Pract } \\
\text { each }\end{array}$ \\
\hline $\begin{array}{l}\text { Colleges } \\
\text { under } \mathrm{MCI}\end{array}$ & 10 & 10 & $40+\operatorname{VIVA}(10)$ & 30 & 100 & $\begin{array}{l}50 \% \text { Theory \& Pract } \\
\text { each }\end{array}$ \\
\hline BPKIHS & \multicolumn{5}{|c|}{ Taken as a part of Surgery paper } & $\begin{array}{l}50 \% \text { Theory \& Pract } \\
\text { each }\end{array}$ \\
\hline AllMS & & 75 & 10 & 15 & 100 & - \\
\hline
\end{tabular}

Examination system in T.U., K.U., and medical colleges under $\mathrm{MCl}$ have maximum marks for final exams. AllMS emphasized more in formative or internal exams. In BPKIHS curriculum there is no seperate ENT paper but it is a part of General Surgery and allied science. It is not necessary to pass ENT section seperatelywhere even though you fail individually in ENT but has done good in other subjects of Surgery there is chance to pass. Internship is elective in K.U., AlIMS, BPKIHS where student can choose other posting instead of ENT. But in T.U. and other medical colleges of India under $\mathrm{MCl}$ it is compulsory for 2 weeks. In T.U. at least 2 night duties should be done in 2 weeks. The procedures to be done in internship are given in table 3 .
Table3: Skills to be developed in Internship

\begin{tabular}{|l|l|l|l|l|}
\hline PROCEDURES & T.U. & K.U. & BPKIHS & Colleges Under MCI \\
\hline FB Removal Ear & $\sqrt{ }$ & $\sqrt{ }$ & $\sqrt{ }$ & $\sqrt{ }$ \\
\hline FB Removal Nose & $\sqrt{ }$ & $\sqrt{ }$ & $\sqrt{ }$ & $\sqrt{ }$ \\
\hline Syringing & $\sqrt{ }$ & & $\sqrt{ }$ & $\sqrt{ }$ \\
\hline Chemical cautery in Epistaxis & $\sqrt{ }$ & & & \\
\hline Ant Nasal Packing & $\sqrt{ }$ & & $\sqrt{ }$ & $\sqrt{ }$ \\
\hline Quinsy I \& D & $\sqrt{ }$ & & $\checkmark$ & \\
\hline Cricothyroidotomy/tracheostomy & & & $\sqrt{ }$ & $\checkmark$ \\
\hline I/G Packing & $\sqrt{ }$ & & & \\
\hline Caloric test & $\sqrt{ }$ & & & \\
\hline Antral wash & & & $\sqrt{ }$ \\
\hline
\end{tabular}

\section{DISCUSSION}

Although the complexities of medical care are increasing, the methods of teaching medicine have changed little. ${ }^{6}$ Even in developed countries curriculum regarding ENT is not as per need for medical graduate. ENT has been removed from the curriculum of nine of the 29 medical schools in the United Kingdom, as it was not deemed relevant to general medical practice. But in a survey done by Sharma et al in 2006 showed , 90 per cent felt their undergraduate ENT teaching was directly beneficial to working in Accidents \& Emergency department, 75 per cent felt they had not received enough undergraduate ENT teaching. ${ }^{7}$ Nepal has seen a dramatic increase in the number of medical schools/colleges in the last decade. It is important to explore the current advances and practices in medical education to meet the needs of the health services of the country. ${ }^{8}$ Teaching learning activities in most of medical colleges of Nepal is by traditional approach. Dhungel et al in their survey over medical students found that only $5.0 \%$ use to surf the internet regularly for their study matter and $79.0 \%$ students had never consulted any medical journals. ${ }^{9}$ Though strong need to standardize the entrance selection procedure of MBBS is being felt, ${ }^{10,11}$ but curriculum standardization is immediate requirement. Regular evaluation of curriculum and syllabus of ENT-HNS during MBBS is must as it is fast growing field and a large proportion of population is being affected by ENT diseases. Most of Nepal Medical Council registered doctors are being trained in Nepal itself, so improving the standard of syllabus, improves quality of health care delivery system. Training Programme in ENT HNS in almost all institution has prime aim of providing basic principles and practice of ENT followed by curative and then preventive aspect. But in AlIMS curriculum of performing surgical procedures has also been targeted.Current syllabus of T.U. has less time allocated for theory lectures almost half of what K.U, has. But topics covered as almost same. Practical classes are given more time in T.U. and least in K.U. Weeks allocated for ward posting is almost half of Indian Institution. But overall time allocated is almost same in different institution. In theory lectures T.U. curriculum involves base of skull and orbit which is not so much important during undergraduate training period but it lacks Head and Neck malignancies in their curriculum, which is nowadays rapidly growing up. Curriculum in AlIMS in addition has focused on principles of common surgeries which are again not much related to undergraduate as the surgeries like myringoplasty, septoplasty, tympanoplasty need not to be dealt at periphery and can be referred at appropriate centers. Undergraduate training should help a doctor to differentiate 
emergency from non emergency cases, and timely referral and appropriate management of common and immediate attention requiring conditions. Seminars by students is being mentioned in curriculum of BPKIHS only. PBL though being done in basics sciences of KUMS curriculum is not been started in clinical subjects as ENT-HNS.Time allocated for ward postings in T.U. though seems to be highest but is not practically feasible and according to medical college it differs slightly. NMC guidelines of bed per student though may be fulfilled by college in totality but in practice for ENT it is not being followed in some medical colleges. Similar is the scenario of teacher per student. Log book during posting is mentioned In IOM Curriculum and not in other medical colleges and not even in that of India. Internal examination being taken in AlIMS is not being incorporated in T.U., BPKIHS. But K.U. curriculum has end semester exams for evaluation of students. During examination AlIMS more focuses in internal assessment, while BPKIHS takes exams under surgery paper and separately passing in ENT/HNS is not required. In that Perspective T.U., K.U. curriculum is better. Internship is optional in K.U., AIIMS, and BPKIHS. It is not needed to do in ENT if one has done internship in other specialty like Psychiatry. But ENT disease burden in community is so much that a graduate must have idea of managing the common problem under supervision which can be done during internship. This part if only is changed and is done as of other medical colleges of India and T.U. then confidence of medical officer to manage ENT condition is quite good.

CONCLUSION AND RECOMMENDATION: Time allocated for theory lectures in T.U. and ward posting in K.U. is less compared to other universities and need of focusing on head and neck lesion is must. Regular examinations and making internship a compulsory posting should be done. Timely and frequent re-evaluation of curriculum to make it time appropriate is recommended.

1. Bachelor Of Medicine and Bachelor of Surgery(MBBS)Curriculum Maharajgunj campus, IOM, 1994

2. Curriculum for Bachelor Of Medicine and Bachelor of Surgery(MBBS)part two, clinical sciences, Kathmandu University, Dhulikhel, Kavre,2006

3. Curriculum for MBBS, BPK Institute of Health Science, Aug 2007

4. Syllabus MBBS at the AlIMS, All India Institute of Medical Sciences, 2nd Ed, July 2005

5. Nepal Medical Council Guidelines, 1997. NMC, Kathmandu.

6. Nandi PL, Chan JN, Chan CP, et al, Undergraduate medical education: comparison of problem-based learning and conventional teaching HKMJ 2000;6:301-6

7. Sharma A, Machen $\mathrm{K}$, Clarke $\mathrm{B}$, et al. Is undergraduate otorhinolaryngology teaching relevant to junior doctors working in accident and emergency departments? J Laryngol Otol. 2006;120(11):949-51.

8. Marahatta SB, Dixit H. Students' perception regarding medical education in Nepal. Kathmandu Univ Med J (KUMJ). 2008;6(2):273-83.

9. Dhungel KU, Prajapati R, Pramanik T, et al. Study habits and attitude of medical students of basic sciences. Nepal Med Coll J. 2007;9(2):129-31

10. Niraula SR, Khanal SS. Critical analysis of performance of medical students. Educ Health (Abingdon). 2006;19(1):5-13.

11. Sharma SC, Maharjan S. Entry knowledge and situational feedback of MBBS students. Kathmandu Univ Med J (KUMJ). 2005;3(4):442-8. 